\title{
Relationship between Plasma Concentrations of Afatinib and the Onset of Diarrhea in Patients with Non-Small Cell Lung Cancer
}

\author{
Hayato Yokota ${ }^{1}$, Kazuhiro Sato ${ }^{2}$, Sho Sakamoto ${ }^{2}$, Yuji Okuda ${ }^{2}$, Mariko Asano ${ }^{2}$, Masahide Takeda ${ }^{2}$, \\ Katsutoshi Nakayama ${ }^{2}$ and Masatomo Miura ${ }^{1, *(D)}$ \\ 1 Department of Pharmacy, Akita University Hospital, Akita 010-8543, Japan; hayato@hos.akita-u.ac.jp \\ 2 Department of Internal Medicine, Division of Respiratory Medicine, Akita University School of Medicine, \\ Akita 010-8543, Japan; kazuhiro@doc.med.akita-u.ac.jp (K.S.); ssakamoto@med.akita-u.ac.jp (S.S.); \\ yokuda@med.akita-u.ac.jp (Y.O.); nmari@doc.med.akita-u.ac.jp (M.A.); takeda-56@hos.akita-u.ac.jp (M.T.); \\ kat_n1@med.akita-u.ac.jp (K.N.) \\ * Correspondence: m-miura@hos.akita-u.ac.jp; Tel.: +81-18-884-6310
}

check for

updates

Citation: Yokota, H.; Sato, K.;

Sakamoto, S.; Okuda, Y.; Asano, M.;

Takeda, M.; Nakayama, K.; Miura, M.

Relationship between Plasma

Concentrations of Afatinib and the Onset of Diarrhea in Patients with

Non-Small Cell Lung Cancer. Biology

2021, 10, 1054. https://doi.org/

10.3390/biology10101054

Academic Editor: Dirk Rades

Received: 24 September 2021

Accepted: 11 October 2021

Published: 17 October 2021

Publisher's Note: MDPI stays neutral with regard to jurisdictional claims in published maps and institutional affiliations.

Copyright: (c) 2021 by the authors Licensee MDPI, Basel, Switzerland. This article is an open access article distributed under the terms and conditions of the Creative Commons Attribution (CC BY) license (https:// creativecommons.org/licenses/by/ $4.0 /)$.
Simple Summary: Higher afatinib plasma concentrations have been reported to be associated with the severity of diarrhea; however, the specific target plasma concentration of afatinib required to avoid severe diarrhea onset is unclear. We found that an afatinib $\mathrm{AUC}_{0-24}$ of greater than or equal to $823.5 \mathrm{ng} \cdot \mathrm{h} / \mathrm{mL}$ and $\mathrm{C}_{0}$ of greater than or equal to $28.5 \mathrm{ng} / \mathrm{mL}$ may be used as cut-off values for the incidence of afatinib-induced grade 2 diarrhea. A significant correlation between the $\mathrm{AUC}_{0-24}$ and $\mathrm{C}_{0}$ of afatinib was observed $\left(r^{2}=0.761 ; p<0.001\right)$. Therefore, we could use $\mathrm{C}_{0}$ as a marker of therapeutic drug monitoring. In the current study, the median time to the incidence of grade 2 diarrhea in patients with a $\mathrm{C}_{0}$ of more than $28.5 \mathrm{ng} / \mathrm{mL}$ was 16 days. Therefore, we recommend monitoring the $\mathrm{C}_{0}$ of afatinib on day 8 after the beginning of afatinib therapy.

Abstract: We evaluated the area under the plasma concentration-time curve (AUC) of afatinib required to avoid the onset of grade 2 or higher diarrhea. The $C_{0}$ and $\mathrm{AUC}_{0-24}$ of afatinib were significant higher in patients with grade 2 diarrhea than in those with grade $0-1$ diarrhea. The areas under the receiver operator curves were 0.795 with the highest sensitivity (89\%) and specificity $(74 \%)$ at an $\mathrm{AUC}_{0-24}$ threshold of $823.5 \mathrm{ng} \cdot \mathrm{h} / \mathrm{mL}$, and 0.754 with the highest sensitivity $(89 \%)$ and specificity (74\%) at a $\mathrm{C}_{0}$ threshold of $28.5 \mathrm{ng} / \mathrm{mL}$. In Kaplan-Meier analysis based on these cut-off $\mathrm{AUC}_{0-24}$ and $\mathrm{C}_{0}$ values, the median time to the incidence of grade 2 diarrhea was 16 days. The predicted $\mathrm{AUC}_{0-24}$ of afatinib from the single point of $\mathrm{C}_{6}$ showed the highest correlation with the measured $\mathrm{AUC}_{0-24}$ $\left(r^{2}=0.840\right)$; however, a significant correlation between the $\mathrm{AUC}_{0-24}$ and $\mathrm{C}_{0}$ was also observed $\left(r^{2}=0.761\right) . C_{0}$ could be used as a marker of therapeutic drug monitoring because afatinib $\mathrm{C}_{0}$ was related to $\mathrm{AUC}_{0-24}$. Therefore, afatinib $\mathrm{C}_{0}$ should be monitored on day 8 after beginning therapy, and the daily dose of afatinib should be adjusted as an index with a cut-off value of $28.5 \mathrm{ng} / \mathrm{mL}$.

Keywords: afatinib; diarrhea; limited sampling strategy; plasma concentration; therapeutic drug monitoring

\section{Introduction}

Afatinib is a second-generation tyrosine kinase inhibitor and irreversible ErbB-family blocker that is used for the first-line treatment of patients with epidermal growth factor receptor (EGFR) mutation-positive non-small cell lung cancer (NSCLC) [1]. Diarrhea is a common side effect associated with afatinib treatment [2-8], and in clinical practice, the onset of diarrhea following afatinib treatment results in temporary withdrawal or discontinuation of therapy. Among EGFR-tyrosine kinase inhibitor (TKI) treatments, afatinib causes a significantly higher rate of diarrhea than erlotinib or gefitinib [9-11]. 
In the Japanese analysis of the LUX-Lung3 clinical trial, $75.9 \%$ of patients administered afatinib therapy required a dose reduction owing to severe side effects, $22 \%$ of which were diarrhea of Common Terminology Criteria for Adverse Events (CTCAE) grade 3 [12] Afatinib-induced diarrhea has been reported to occur in $50-62 \%$ of patients within the first 7 days of treatment and in $71 \%$ of patients within 14 days [13]. However, the mechanisms of afatinib-induced diarrhea remain poorly understood.

To date, higher afatinib plasma concentrations have been reported to be associated with the severity of diarrhea [14-18]. Therefore, the analysis of plasma concentrations of afatinib may enable the avoidance of diarrhea onset. However, the specific target plasma concentration of afatinib required to avoid severe diarrhea onset is not clear. The area under the plasma concentration-time curve (AUC) is generally the best parameter to indicate drug exposure, and the calculation of AUC is important for assessing the relationships between drug exposure and side effects. However, the calculation of AUC is rarely used in clinical practice because it requires multiple blood sample points, which is painful and time-consuming for patients. Therefore, the plasma trough concentration $\left(\mathrm{C}_{0}\right)$ at pre-dose is usually used to predict efficacy or toxicity, although one point of $\mathrm{C}_{0}$ may not accurately indicate afatinib exposure. Limited sampling strategies (LSSs) have been proposed to overcome these difficulties. However, the LSS for predicting the AUC of afatinib has not yet been reported.

Accordingly, in this study, we calculated the target $\mathrm{AUC}_{0-24}$ of afatinib to avoid the onset of CTCAE grade 2 or higher diarrhea. In addition, we developed a model to predict the $\mathrm{AUC}_{0-24}$ of afatinib using an LSS. Subsequently, we investigated whether the predicted $\mathrm{AUC}_{0-24}$ of afatinib from $\mathrm{C}_{0}$ alone could provide an accurate approximation of the actual $\mathrm{AUC}_{0-24}$.

\section{Materials and Methods}

\subsection{Patients and Protocols}

Thirty-one Japanese patients with EGFR mutation-positive NSCLC (15 women and 16 men) who were hospitalized from October 2014 through December 2020 were consecutively enrolled in this study. The grade for diarrhea was determined based on CTCAE version 4.0. Three patients ( 2 women and 1 man) were excluded because of withdrawal due to CTCAE grade 3 diarrhea just after beginning and before blood sampling for afatinib pharmacokinetics. Patient characteristics at the start of afatinib therapy are listed in Table 1. The study protocol was approved by the Ethics Committee of Akita University School of Medicine (approval no. 790), and all patients gave written informed consent. This study was performed in accordance with the guidelines of the Declaration of Helsinki.

An initial dose of 30 or $40 \mathrm{mg}$ afatinib (Giotrif; Boehringer Ingelheim, Tokyo, Japan) was orally administered once daily at a designated time (11:00 a.m.). On day 15 after beginning afatinib therapy, whole blood samples were collected just prior to $\left(\mathrm{C}_{0}, 24 \mathrm{~h}\right.$ after the 14th administration) and at 1, 2, 4, 6, 8, 12, and $24 \mathrm{~h}$ after the 15th administration of afatinib. Plasma was isolated by centrifugation at $1900 \times g$ for $15 \mathrm{~min}$ and was stored at $-80{ }^{\circ} \mathrm{C}$ until analysis. For the 15 days prior to plasma sampling, nurses managed the administration of afatinib for hospitalized patients.

Table 1. Demographic and clinical characteristics of patients prior to afatinib therapy.

\begin{tabular}{|c|c|c|}
\hline Characteristics & \multicolumn{2}{|c|}{ Number or Values } \\
\hline Total number & \multicolumn{2}{|c|}{28} \\
\hline Female:Male & \multicolumn{2}{|c|}{$13: 15$} \\
\hline Age, years & $67.4 \pm 7.7$ & $(51-86)$ \\
\hline Body weight, kg & $57.3 \pm 9.4$ & $(35.3-78.3)$ \\
\hline Body surface area, $\mathrm{m}^{2}$ & $1.59 \pm 0.16$ & (1.23-1.93) \\
\hline Body mass index, $\mathrm{kg} / \mathrm{m}^{2}$ & $22.7 \pm 1.5$ & $(19.8-25.8)$ \\
\hline
\end{tabular}


Table 1. Cont.

\begin{tabular}{|c|c|c|}
\hline \multirow{2}{*}{$\begin{array}{l}\text { Characteristics } \\
\text { Laboratory test values }\end{array}$} & \multicolumn{2}{|c|}{ Number or Values } \\
\hline & & \\
\hline White blood cell, $\times 10^{3} / \mathrm{mm}^{3}$ & $5.7 \pm 1.4$ & $(3.7-10.4)$ \\
\hline Red blood cell, $\times 10^{4} / \mathrm{mm}^{3}$ & $422 \pm 43$ & $(342-498)$ \\
\hline Hemoglobin, g/dL & $12.6 \pm 1.7$ & $(8-15)$ \\
\hline Platelets, $\times 10^{4} / \mathrm{mm}^{3}$ & $238 \pm 59$ & $(122-366)$ \\
\hline Aspartate aminotransferase, IU/L & $22.4 \pm 5.4$ & $(12-39)$ \\
\hline Alanine aminotransferase, IU/L & $16.9 \pm 5.6$ & $(8-30)$ \\
\hline Alkaline phosphatase, IU/L & $314 \pm 218$ & $(115-1336)$ \\
\hline Lactate dehydrogenase, IU / L & $219 \pm 92$ & $(135-601)$ \\
\hline Serum albumin, $\mathrm{g} / \mathrm{dL}$ & $3.8 \pm 0.4$ & $(2.8-4.6)$ \\
\hline Total bilirubin, $\mathrm{mg} / \mathrm{dL}$ & $0.5 \pm 0.2$ & $(0.3-1.1)$ \\
\hline Serum creatinine, $\mathrm{mg} / \mathrm{dL}$ & $0.69 \pm 0.21$ & $(0.43-1.30)$ \\
\hline $\mathrm{eGFR}, \mathrm{mL} / \mathrm{min} / 1.73 \mathrm{~m}^{2}$ & $82.4 \pm 21.4$ & $(43.6-125.5)$ \\
\hline Stage IV:IIIb:IIb & \multicolumn{2}{|c|}{$26: 1: 1$} \\
\hline Tumor history, adenocarcinoma:other & \multicolumn{2}{|c|}{$28: 0$} \\
\hline EGFR mutation, exon 19 deletions:exon & \multicolumn{2}{|c|}{$16: 7: 5$} \\
\hline Initial dose, $30 \mathrm{mg}: 40 \mathrm{mg}$ & \multicolumn{2}{|c|}{$7: 21$} \\
\hline Diarrhea (grade 1:2): no diarrhea & \multicolumn{2}{|c|}{$23(14: 9): 5$} \\
\hline
\end{tabular}

\subsection{Analytical Methods}

Plasma concentrations of afatinib were measured by high-performance liquid chromatography (HPLC) and ultraviolet methods, as previously described [19-21]. Following the addition of gefitinib ( $5 \mathrm{ng} / 10 \mu \mathrm{L}$ methanol) as an internal standard to a $200-\mu \mathrm{L}$ plasma sample, the plasma sample was diluted with $800 \mu \mathrm{L}$ water and vortexed for $30 \mathrm{~s}$. This mixture was applied to an Oasis hydrophilic lipophilic balance extraction cartridge $(1 \mathrm{~mL}$, $30 \mathrm{mg}$ ) that had been activated previously with methanol and water $(1.0 \mathrm{~mL}$ each). The cartridge was then washed with $1.0 \mathrm{~mL}$ water and $1.0 \mathrm{~mL}$ of $60 \%$ methanol in water and eluted with $1.0 \mathrm{~mL}$ of $100 \%$ methanol. Eluates were dried by vortex-vacuum evaporation at $70{ }^{\circ} \mathrm{C}$ using a rotary evaporator (AS-ONE CVE-2AS; Osaka, Japan). The resulting residue was then dissolved in $20 \mu \mathrm{L}$ methanol and vortexed for $30 \mathrm{~s} ; 20 \mu \mathrm{L}$ of the mobile phase was added to the sample, and the sample was vortexed for another $30 \mathrm{~s}$. A 20- $\mu \mathrm{L}$ aliquot of the sample was then processed by HPLC. The calibration curve of afatinib in plasma was linear over the concentration range of 5 to $250 \mathrm{ng} / \mathrm{mL}$. The limit of quantification of afatinib for this assay was $5 \mathrm{ng} / \mathrm{mL}$. The coefficients of variation and accuracies for intraand interday assays at the concentration range of 5 to $250 \mathrm{ng} / \mathrm{mL}$ were less than $12.4 \%$ and within $11.3 \%$, respectively.

\subsection{Pharmacokinetic Analysis}

Pharmacokinetic analysis of afatinib was carried out using the standard noncompartmental method with WinNonlin (Pharsight Co., Mountain View, CA, USA; version 5.2). The total area under the observed plasma concentration-time curve (AUC) and the partial AUC from 6 to $12 \mathrm{~h}\left(\mathrm{AUC}_{6-12}\right)$, which are estimates of enterohepatic circulation, were calculated using the linear trapezoidal rule. The maximum plasma concentration $\left(\mathrm{C}_{\max }\right)$ and minimum plasma concentration $\left(\mathrm{C}_{\mathrm{min}}\right)$ of afatinib were obtained directly from the profile.

\subsection{Statistical Analyses}

The estimated glomerular filtration rate (eGFR) was calculated for each patient according to the following formula: eGFR $=194 \times$ serum creatinine $(\mathrm{mg} / \mathrm{dL})^{-1.094} \times$ age $^{-0.287}$ $\times$ body surface area $\left(\mathrm{m}^{2}\right) / 1.73(\times 0.739$ for women). Shapiro-Wilk tests were used to assess distributions. The clinical characteristics of patients at baseline before afatinib therapy were expressed as the number or mean value \pm standard deviation (SD) (range). The Spearman's rank correlation coefficient test was applied to assess correlations between the 
$\mathrm{AUC}_{0-24}$ of afatinib and clinical characteristics of the patient. Pharmacokinetic parameters of afatinib and the clinical characteristics of patients at the onset of diarrhea were expressed as median values (quartile 1-quartile 3). Pharmacokinetic parameters of afatinib or the clinical characteristics of patients between the two grade groups of afatinib-induced diarrhea classified by CTCAE were compared using the Mann-Whitney test. Receiver operating characteristic (ROC) curves were used to determine the best cut-off values for predictive factors, which had a minimum distance from the upper left corner to the point on the ROC curve. The Kaplan-Meier method and log-rank test were adopted to estimate and compare the cumulative incidence of grade 2 diarrhea. Multiple linear regression analysis of the $\mathrm{AUC}_{0-24}$ best estimates against afatinib concentrations at various time points (independent variables) was performed to develop the prediction formula for estimating individual $\mathrm{AUC}_{0-24}$ values. This analysis produced the following prediction formula: $\mathrm{AUC}_{0-24}=\mathrm{A}_{0}+$ $A_{1} \times C_{1}+A_{2} \times C_{2}+\ldots+A_{n} \times C_{n}$, where $A_{n}$ is the coefficient and the number of samples is variable. The predictive performance of the LSS was determined by the bootstrap method [22]. We generated 1000 bootstrap samples only once to reduce the variability of results for all regression analysis methods. The distribution of the misclassification rate obtained during all bootstrap runs was used to estimate the $95 \%$ confidence interval (CI).

Results with $p$-values less than 0.05 were considered statistically significant. Statistical analyses were performed with IBM SPSS Statistics 27.0 for Windows (SPSS IBM Japan Inc., Tokyo, Japan).

\section{Results}

\subsection{Patient Characteristics}

The characteristics of patients before afatinib therapy are listed in Table 1 . The mean ( \pm SD) age of patients was $67.4 \pm 7.7$ years, and the means ( \pm SDs) of body weight, body surface area, and body mass index were $57.3 \pm 9.4 \mathrm{~kg}, 1.59 \pm 0.16 \mathrm{~m}^{2}$, and $22.7 \pm 1.5 \mathrm{~kg} / \mathrm{m}^{2}$, respectively. There were no patients with serious renal or hepatic dysfunction before afatinib therapy. The numbers of patients with stage IV, IIIb, and IIb adenocarcinoma were 26, 1, and 1, respectively. The types of EGFR mutations were as follows: exon 19 deletions in 16 patients, exon 21 L858R in 7 patients, and other in 5 patients.

\subsection{Afatinib Plasma Concentration-Time Profiles and Correlations between the $A U C_{0-24}$ and Clinical Characteristics}

Plasma concentration-time profiles from 0 to $24 \mathrm{~h}$ after the administration of afatinib on day 15 after the beginning of therapy in 28 patients are shown in Figure 1. The median (range) $\mathrm{C}_{0}, \mathrm{C}_{\max }$, and $\mathrm{AUC}_{0-24}$ of afatinib at the steady state on day 15 in seven patients receiving $30 \mathrm{mg} /$ day afatinib therapy were $23.3(10.2-43.6) \mathrm{ng} / \mathrm{mL}, 38.9(18.8-96.7) \mathrm{ng} / \mathrm{mL}$, and $662(357-1225) \mathrm{ng} \cdot \mathrm{h} / \mathrm{mL}$, respectively. In 21 patients receiving $40 \mathrm{mg} /$ day afatinib therapy, the steady-state median (range) $\mathrm{C}_{0}, \mathrm{C}_{\max }$, and $\mathrm{AUC}_{0-24}$ of afatinib were 30.4 (8.5-59.5) ng/mL, 47.9 (17.7-90.5) ng/mL, and 848 (289-1480) ng.h/mL, respectively. There were no significant differences in the $\mathrm{C}_{0}, \mathrm{C}_{\max }$, and $\mathrm{AUC}_{0-24}$ of afatinib between patients receiving 30 and $40 \mathrm{mg} /$ day doses. The interpatient variabilities (coefficients of variation) in afatinib $\mathrm{C}_{0}$ at 30 and $40 \mathrm{mg} /$ day doses were $50.8 \%$ and $46.6 \%$, respectively. The correlations between the $\mathrm{AUC}_{0-24}$ of afatinib and clinical characteristics of patients are shown in Table 2; however, there were no significant correlations.

\subsection{Comparisons of Afatinib Pharmacokinetic Parameters or Clinical Characteristics between Patients with Grade 2 or Grade 0-1 Diarrhea}

Comparisons of the pharmacokinetic parameters of afatinib or clinical characteristics of patients according to diarrhea grade (2 versus $0-1$ ) are shown in Table 3 . There were no patients with grade 3 diarrhea. The $C_{\max }, C_{0}, C_{\min }, \mathrm{AUC}_{0-24}$, and $\mathrm{AUC}_{6-24}$ of afatinib in patients with grade 2 diarrhea were significantly higher than those in patients with grade 0-1 diarrhea; however, there were no significant differences in the clinical characteristics of patients between the two groups. In addition, there were no significant differences in the 
$\mathrm{C}_{\max } / \mathrm{C}_{\min }$ ratio and $\mathrm{AUC}_{6-24} / \mathrm{AUC}_{0-24}$ ratio, which is the enterohepatic circulation rate, of afatinib between the two groups (Table 3 ).

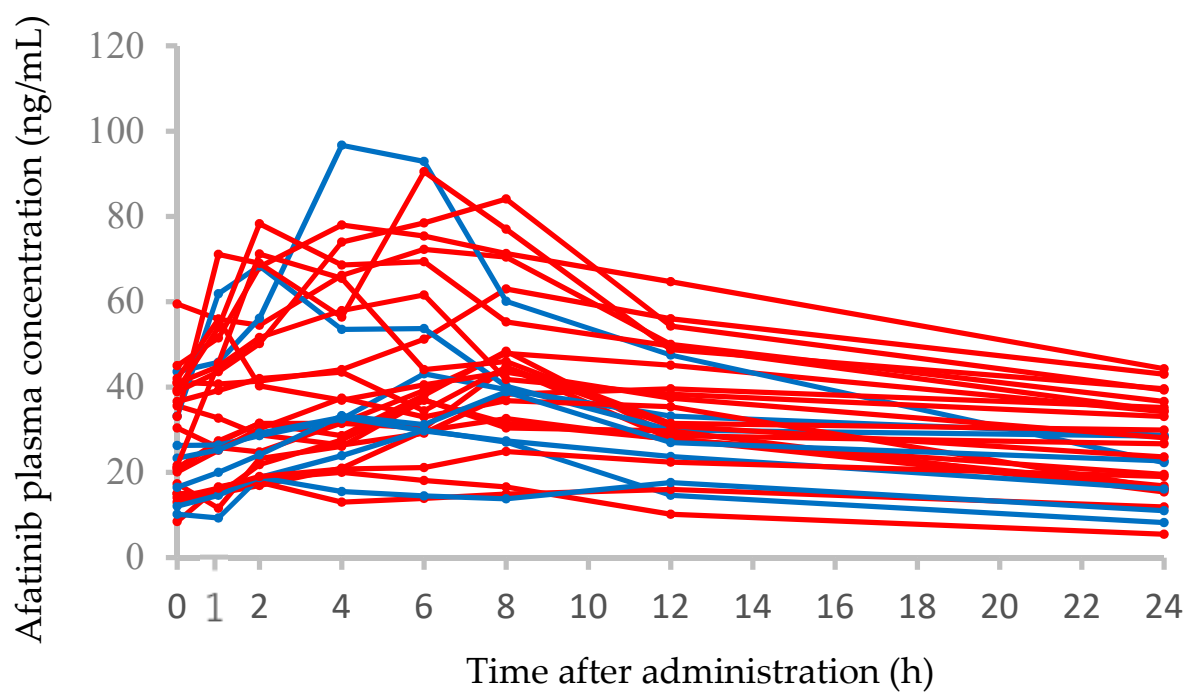

Figure 1. Plasma concentration-time profiles of afatinib in 28 patients administered afatinib at $30 \mathrm{mg}$ / day (blue solid line) or $40 \mathrm{mg} /$ day (red solid line).

Table 2. Comparison and correlations of afatinib $\mathrm{AUC}_{0-24}$ with clinical characteristics of patients.

\begin{tabular}{lcc}
\hline \multicolumn{1}{c}{ Characteristics } & Median AUC $_{\mathbf{0}-\mathbf{2 4}}$ (Range), $\mathbf{n g} \cdot \mathbf{h} / \mathbf{m L}$ & $\boldsymbol{p}$-Value \\
\hline Female & $848(574-1480)$ & 0.205 \\
Male & $753(289-1366)$ & $p$-Value \\
\hline & Correlation Coefficient (r) & 0.850 \\
\hline Age & 0.037 & 0.070 \\
Body weight & -3.480 & 0.192 \\
Body surface area & -2.540 & 0.799 \\
BMI & -0.050 & \\
Laboratory test values & & 0.561 \\
White blood cell & 0.115 & 0.130 \\
Red blood cell & -0.293 & 0.136 \\
Hemoglobin & -0.289 & 0.444 \\
Platelets & -0.151 & 0.138 \\
Aspartate aminotransferase & 0.287 & 0.386 \\
Alanine aminotransferase & -0.171 & 0.056 \\
Alkaline phosphatase & -0.365 & 0.217 \\
Lactate dehydrogenase & 0.241 & 0.991 \\
Serum albumin & -0.002 & 0.546 \\
Total bilirubin & 0.119 & 0.724 \\
Serum creatinine & -0.070 & 0.587 \\
eGFR & -0.107 & \\
\hline AUC & &
\end{tabular}

$\overline{\mathrm{AUC}}_{0-24}$, area under the plasma concentration-time curve from 0 to 24; eGFR, estimated glomerular filtration rate.

\subsection{ROC Analysis and Kaplan-Meier Curves of Afatinib for the Incidence of Grade 2 Diarrhea}

ROC analysis showed the discrimination potential of the $\mathrm{AUC}_{0-24}$ or $\mathrm{C}_{0}$ of afatinib for the incidence of grade 2 diarrhea (Figure 2). The areas under the ROC curves were 0.795 with the highest sensitivity $(89 \%)$ and specificity $(74 \%)$ at an $\mathrm{AUC}_{0-24}$ threshold of $823.5 \mathrm{ng} \cdot \mathrm{h} / \mathrm{mL}$ and 0.754 with the highest sensitivity $(89 \%)$ and specificity $(74 \%)$ at a $\mathrm{C}_{0}$ threshold of $28.5 \mathrm{ng} / \mathrm{mL}$. Kaplan-Meier analyses for times to the incidence of grade 2 diarrhea based on these cut-off values of $\mathrm{AUC}_{0-24}(823.5 \mathrm{ng} \cdot \mathrm{h} / \mathrm{mL})$ and $\mathrm{C}_{0}(28.5 \mathrm{ng} / \mathrm{mL})$ of afatinib are shown in Figure 3. In patients with an $\mathrm{AUC}_{0-24}$ of greater than or equal to $823.5 \mathrm{ng} \cdot \mathrm{h} / \mathrm{mL}$ and a $\mathrm{C}_{0}$ of greater than or equal to $28.5 \mathrm{ng} / \mathrm{mL}$, the median $(95 \% \mathrm{CI})$ time 
to the incidence of grade 2 diarrhea was 16 (8-24) days. There was a statistically significant difference in the median time to the incidence of grade 2 diarrhea between patients with an $\mathrm{AUC}_{0-24}$ of greater than or equal to $823.5 \mathrm{ng} \cdot \mathrm{h} / \mathrm{mL}$ and less than $823.5 \mathrm{ng} \cdot \mathrm{h} / \mathrm{mL}$ or a $\mathrm{C}_{0}$ of greater than or equal to $28.5 \mathrm{ng} / \mathrm{mL}$ and less than $28.5 \mathrm{ng} / \mathrm{mL}$ (each $p=0.009$, Figure 3).

Table 3. Comparison of pharmacokinetics of afatinib and characteristics between patients with grades 2 and $0-1$ diarrhea.

\begin{tabular}{|c|c|c|c|}
\hline \multirow[b]{2}{*}{ Parameters/Characteristics } & Grade 2 Diarrhea & Grade 0-1 Diarrhea & \multirow[b]{2}{*}{$p$-Value } \\
\hline & $\begin{array}{c}\text { Median } \\
\text { (Quartile 1-Quartile 3) }\end{array}$ & $\begin{array}{c}\text { Median } \\
\text { (Quartile 1-Quartile 3) }\end{array}$ & \\
\hline $\mathrm{C}_{\max }(\mathrm{ng} / \mathrm{mL})$ & $78.0(47.9-84.1)$ & $38.9(32.8-55.0)$ & 0.017 \\
\hline $\mathrm{C}_{0}(\mathrm{ng} / \mathrm{mL})$ & $38.9(33.1-42.0)$ & $21.0(15.0-29.8)$ & 0.032 \\
\hline $\mathrm{C}_{\min }(\mathrm{ng} / \mathrm{mL})$ & $28.1(24.8-34.4)$ & $16.5(14.5-25.0)$ & 0.046 \\
\hline $\mathrm{C}_{\max } / \mathrm{C}_{\min }$ ratio & $2.20(1.90-2.70)$ & $2.20(1.75-2.45)$ & 0.657 \\
\hline $\mathrm{AUC}_{0-24}(\mathrm{ng} \cdot \mathrm{h} / \mathrm{mL})$ & 1225 (891-1344) & $666(580-863)$ & 0.013 \\
\hline $\mathrm{AUC}_{6-24}(\mathrm{ng} \cdot \mathrm{h} / \mathrm{mL})$ & 787 (672-950) & $500(424-592)$ & 0.007 \\
\hline $\mathrm{AUC}_{6-24} / \mathrm{AUC}_{0-24} \times 100(\%)$ & $71.7(67.8-73.3)$ & $73.6(69.7-75.8)$ & 0.389 \\
\hline Daily dose, $30 \mathrm{mg}: 40 \mathrm{mg}$ & $1: 8$ & $6: 13$ & 0.249 \\
\hline Female:male & $6: 3$ & $7: 12$ & 0.142 \\
\hline Age, years & $65.0(62.0-71.0)$ & $67.0(63.5-73.5)$ & 0.693 \\
\hline Body weight, kg & $50.5(46.7-56.0)$ & $56.2(53.2-64.3)$ & 0.085 \\
\hline Body surface area, $\mathrm{m}^{2}$ & $1.54(1.41-1.57)$ & $1.60(1.54-1.73)$ & 0.109 \\
\hline BMI, $\mathrm{kg} / \mathrm{m}^{2}$ & $22.9(22.8-23.3)$ & $23.0(21.3-23.4)$ & 0.694 \\
\hline \multicolumn{4}{|l|}{ Laboratory test values } \\
\hline White blood cell, $\times 10^{3} / \mathrm{mm}^{3}$ & $5.3(4.0-6.9)$ & $5.4(4.1-6.0)$ & 0.825 \\
\hline Red blood cell, $\times 10^{4} / \mathrm{mm}^{3}$ & $405(384-430)$ & $413(372-455)$ & 0.640 \\
\hline Hemoglobin, g/dL & $12.1(11.5-12.4)$ & $12.5(11.5-13.6)$ & 0.403 \\
\hline Platelets, $\times 10^{4} / \mathrm{mm}^{3}$ & $21.4(16.6-23.1)$ & $23.7(20.6-27.2)$ & 0.210 \\
\hline Aspartate aminotransferase, IU/L & $21(18-22)$ & $19(18-28)$ & 0.730 \\
\hline Alanine aminotransferase, IU/L & $15(11-28)$ & $18(14-25)$ & 0.362 \\
\hline Alkaline phosphatase, IU/L & $241(211-419)$ & $261(226-290)$ & 0.825 \\
\hline Lactate dehydrogenase, IU/L & $174(156-191)$ & $176(160-217)$ & 0.980 \\
\hline Serum albumin, $\mathrm{g} / \mathrm{dL}$ & $3.4(3.3-3.6)$ & $3.7(3.4-3.9)$ & 0.311 \\
\hline Total bilirubin, mg/dL & $0.5(0.4-0.7)$ & $0.5(0.4-0.6)$ & 0.439 \\
\hline Serum creatinine, $\mathrm{mg} / \mathrm{dL}$ & $0.67(0.56-0.70)$ & $0.74(0.66-0.85)$ & 0.110 \\
\hline $\mathrm{eGFR}, \mathrm{mL} / \mathrm{min} / 1.73 \mathrm{~m}^{2}$ & $78.5(62.3-97.3)$ & $74.1(65.9-82.6)$ & 0.539 \\
\hline
\end{tabular}

Data are presented as number or median (quartile 1-quartile 3). $\mathrm{C}_{\max }$, maximum plasma concentration; $\mathrm{C}_{0}$, predose concentration; $\mathrm{C}_{\min }$, minimum plasma concentration; $\mathrm{AUC}_{0-24}$ and ${ }_{6-24}$, area under the plasma concentrationtime curve from 0 to $24 \mathrm{~h}$ and 6 to $24 \mathrm{~h}$, respectively; eGFR, estimated glomerular filtration rate.

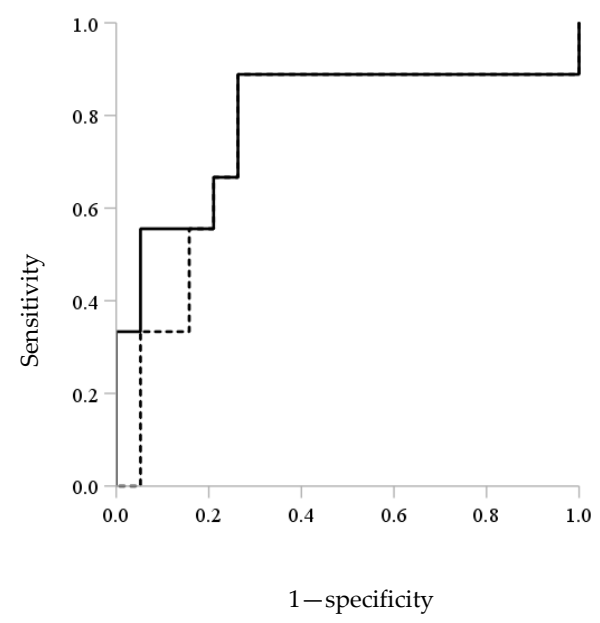

Figure 2. Receiver operator curve (ROC) analysis of the discrimination potential of $\mathrm{AUC}_{0-24}$ (solid line) and $\mathrm{C}_{0}$ (dashed line) of afatinib for the incidence of grade 2 diarrhea. 


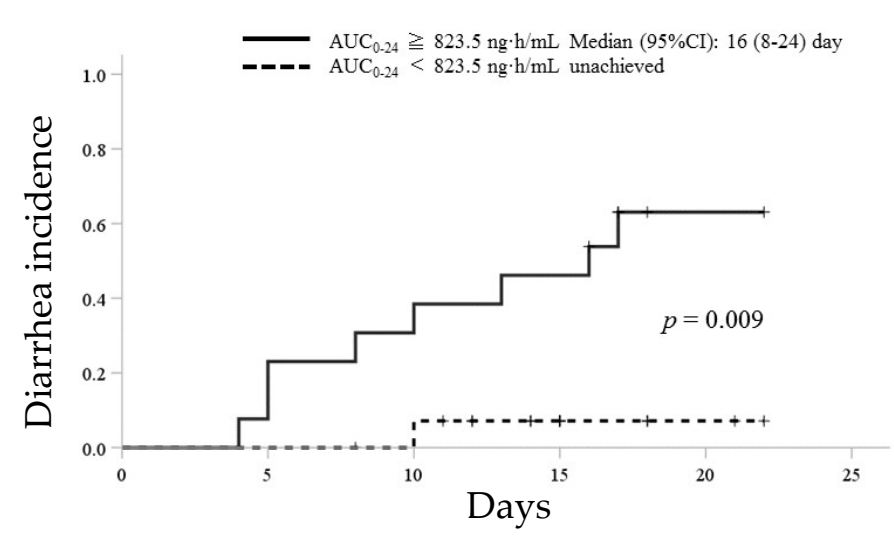

(a)

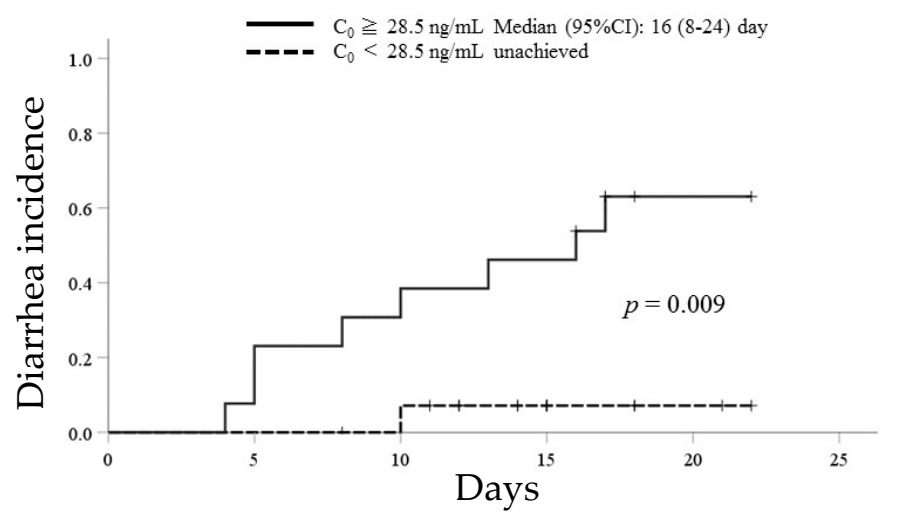

(b)

Figure 3. Kaplan-Meier analysis for time to the incidence of grade 2 diarrhea based on the cut-off values of $A U C_{0-24}$ $(823.5 \mathrm{ng} \cdot \mathrm{h} / \mathrm{mL})$ and $\mathrm{C}_{0}(28.5 \mathrm{ng} / \mathrm{mL})$ of afatinib. Kaplan-Meier curves for the incidence of grade 2 diarrhea in patients with (a) $\mathrm{AUC}_{0-24}$ of greater than or equal to $823.5 \mathrm{ng} \cdot \mathrm{h} / \mathrm{mL}$ (solid line) and less than $823.5 \mathrm{ng} \cdot \mathrm{h} / \mathrm{mL}$ (dotted line) and with (b) $\mathrm{C}_{0}$ of greater than or equal to $28.5 \mathrm{ng} / \mathrm{mL}$ (solid line) and less than $28.5 \mathrm{ng} / \mathrm{mL}$ (dotted line).

\subsection{Prediction Formulae to Estimate the Afatinib $A U C_{0-24}$}

The derived prediction formulae and $r^{2}$ values for the estimation of the $\mathrm{AUC}_{0-24}$ of afatinib with a single point and with the best two-point combinations are shown in Table 4 . Although a significant correlation between the $\mathrm{AUC}_{0-24}$ and $\mathrm{C}_{0}$ of afatinib was observed $\left(r^{2}=0.761 ; p<0.001\right)$, the predicted $\mathrm{AUC}_{0-24}$ of afatinib from the single point of $\mathrm{C}_{6}$ showed the highest correlation with the measured $\mathrm{AUC}_{0-24}$ (predicted $\mathrm{AUC}_{0-24}=14.0 \times \mathrm{C}_{6}+214.6$, $\left.r^{2}=0.840 ; p<0.001\right)$. In addition, the predicted $\mathrm{AUC}_{0-24}$ of afatinib from the two points of $\mathrm{C}_{0}$ and $\mathrm{C}_{6}$ showed the highest correlation with the measured $\mathrm{AUC}_{0-24}$ (predicted $\mathrm{AUC}_{0-24}$ $\left.=10.6 \times \mathrm{C}_{0}+9.1 \times \mathrm{C}_{6}+135.4, r^{2}=0.911 ; p<0.001\right)$.

Table 4. The prediction formulae derived using the multiple linear regression approach to estimate the $\mathrm{AUC}_{0-24}$ of afatinib.

\begin{tabular}{|c|c|c|c|c|c|c|c|c|}
\hline \multirow[t]{2}{*}{ Sampling Numbers } & \multirow[t]{2}{*}{ Sampling Time (h) } & \multirow{2}{*}{$\begin{array}{l}\text { Prediction Formula } \\
\text { for } \mathrm{AUC}_{0-24}\end{array}$} & \multicolumn{2}{|c|}{$\begin{array}{l}\text { Predicted versus } \\
\text { Observed } \text { AUC }_{0-24}\end{array}$} & \multicolumn{2}{|c|}{ Slope } & \multirow[t]{2}{*}{ Intercept $95 \%$ CI * } & \multirow[t]{2}{*}{$p *$} \\
\hline & & & $\mathbf{r}^{2}$ & $p$ & $95 \% \mathrm{CI}^{*}$ & $p^{*}$ & & \\
\hline \multirow[t]{7}{*}{ One-point } & 0 & $22.3 \times C_{0}+215.9$ & 0.761 & $<0.001$ & 17.7 to 28.6 & 0.001 & 85.5 to 331.2 & 0.005 \\
\hline & 1 & $16.4 \times C_{1}+286.1$ & 0.712 & $<0.001$ & 12.2 to 21.8 & 0.001 & 143.7 to 411.0 & 0.001 \\
\hline & 2 & $14.5 \times C_{2}+276.9$ & 0.691 & $<0.001$ & 10.6 to 19.7 & 0.001 & 110.3 to 433.1 & 0.012 \\
\hline & 4 & $13.7 \times \mathrm{C}_{4}+263.4$ & 0.762 & $<0.001$ & 10.5 to 18.0 & 0.001 & 112.1 to 410.0 & 0.007 \\
\hline & 6 & $14.0 \times \mathrm{C}_{6}+214.6$ & 0.840 & $<0.001$ & 11.4 to 17.3 & 0.001 & 81.7 to 334.6 & 0.004 \\
\hline & 8 & $17.5 \times \mathrm{C}_{8}+75.9$ & 0.899 & $<0.001$ & 15.6 to 20.1 & 0.001 & -25.0 to 159.6 & 0.108 \\
\hline & 12 & $23.8 \times \mathrm{C}_{12}+11.9$ & 0.916 & $<0.001$ & 21.6 to 26.7 & 0.001 & -75.2 to 84.7 & 0.770 \\
\hline \multirow[t]{2}{*}{ Two-points $^{\dagger}$} & 0 & $10.6 \times C_{0}+9.1 \times C_{6}+135.4$ & 0.911 & $<0.001$ & 6.1 to 16.5 & 0.003 & 38.8 to 228.5 & 0.022 \\
\hline & 6 & & & & 5.6 to 12.3 & 0.001 & & \\
\hline
\end{tabular}

$\mathrm{AUC}_{0-24}$, area under the plasma concentration-time curve from 0 to $24 \mathrm{~h} ; \mathrm{C}_{n}$, plasma concentration at $n \mathrm{~h}$ after afatinib administration. * Calculated using the bootstrap method. ${ }^{\dagger}$ Best sampling point.

\section{Discussion}

In the current study, the $\mathrm{AUC}_{0-24}$ and $\mathrm{C}_{0}$ of afatinib in patients with grade 2 diarrhea were significantly higher than those in patients with grade $0-1$ diarrhea. We found that an afatinib $\mathrm{AUC}_{0-24}$ of greater than or equal to $823.5 \mathrm{ng} \cdot \mathrm{h} / \mathrm{mL}$ and a $\mathrm{C}_{0}$ of greater than or equal to $28.5 \mathrm{ng} / \mathrm{mL}$ may be used as cut-off values for the incidence of afatinib-induced grade 2 diarrhea. In addition, because afatinib $C_{0}$ is related to $A U C_{0-24}$, we could use $C_{0}$ as a marker of therapeutic drug monitoring. Therefore, we monitored afatinib $C_{0}$ on day 8 after the beginning of therapy to arrive at a steady state [14], and the daily dose of afatinib should be adjusted as an index with a cut-off value of $28.5 \mathrm{ng} / \mathrm{mL}$. In the current study, the median time to the incidence of grade 2 diarrhea in the patients with a $C_{0}$ of more than 
$28.5 \mathrm{ng} / \mathrm{mL}$ was 16 days. Therefore, we recommend monitoring the $\mathrm{C}_{0}$ of afatinib on day 8 after the beginning of afatinib therapy.

A higher afatinib $C_{0}$ has been reported to be related to the severity of diarrhea [15]. In a previous study (the LUX-Lung trials) [15], the median $C_{0}$ values of afatinib in patients with grade 2 or 1 diarrhea following the administration of $40 \mathrm{mg} /$ day afatinib were reported to be 31.6 and $25.2 \mathrm{ng} / \mathrm{mL}$, respectively. In addition, the median $\mathrm{AUC}_{0-24}$ values of afatinib in patients with grade 2 diarrhea in the LUX-Lung trials [14] and our current study were 1320 and $1225 \mathrm{ng} \cdot \mathrm{h} / \mathrm{mL}$, respectively. Thus, the results obtained from the current clinical study were similar to the results of the LUX-Lung trials. To date, studies have suggested that female sex, low body weight, and reduced renal function are associated with higher afatinib exposure [23]. However, in an analysis using data pooled from seven clinical studies, the risk factors of afatinib-induced diarrhea were found to be older age, female sex, and low body weight (less than $45 \mathrm{~kg}$ ) [24]. Therefore, patients with low body weight seem to be at risk of afatinib exposure-dependent diarrhea. Similar to the results of these previous studies $[23,24]$, our current findings also showed that patients with lower body weight tended to have higher afatinib $\operatorname{AUC}_{0-24}(p=0.070)$ and to develop grade 2 diarrhea $(p=0.085)$; however, the results were not significant. Therefore, afatinib therapy with a dose escalation strategy by therapeutic drug monitoring based on the target concentration of $28.5 \mathrm{ng} / \mathrm{mL}$ from a low dose of 20-30 mg/day for patients with a low body weight may be recommended to enable the administration of continuous treatment without interruption due to diarrhea.

Approximately $85 \%$ of afatinib is excreted into the bile as unchanged drug [15]. The biliary secretion of afatinib into the gut may directly induce diarrhea. Therefore, we evaluated the biliary secretion of afatinib using the $\mathrm{AUC}_{6-24} / \mathrm{AUC}_{0-24}$ ratio, which is the enterohepatic circulation rate. The results showed that there were no significant differences in the $\mathrm{AUC}_{6-24} / \mathrm{AUC}_{0-24}$ ratios of afatinib between patients with grade 2 or grade $0-1$ diarrhea. Therefore, afatinib-induced diarrhea does not seem to be caused by the stimulation of the gut via the biliary excretion of afatinib. In addition, there were no significant differences in the $C_{\max } / C_{\min }$ ratio, which indicated the rate of absorption of afatinib, between patients with grade 2 and grade $0-1$ diarrhea. Non-absorbed afatinib from the gut did not appear to contribute to diarrhea directly. By contrast, afatinib-induced diarrhea has been reported to be caused by the activation of apical membrane chloride $\left(\mathrm{Cl}^{-}\right)$channels in the intestinal epithelia rather than direct damage to the epithelium $[25,26]$. Therefore, further studies are necessary to determine the mechanisms mediating the onset of afatinib-induced diarrhea.

Overall, our current findings showed that afatinib exposure, including $\mathrm{AUC}_{0-24}$ and $\mathrm{C}_{0}$, was important for the prediction of grade 2 diarrhea onset.

To the best of our knowledge, no reports have validated an LSS for the prediction of the $\mathrm{AUC}_{0-24}$ of afatinib. Our results showed that $\mathrm{C}_{6}$ was the best single predictor of the $\mathrm{AUC}_{0-24}$ of afatinib, and an equation using samples measured at two specific points $\left(C_{0}\right.$ and $\left.C_{6}\right)$ could best be used to approximate the $A_{U C} C_{0-24}$ of afatinib. However, in outpatients, blood sampling for $\mathrm{C}_{6}$ after the administration of afatinib is difficult. Although the coefficient of determination $\left(r^{2}\right)$ between the predicted $\mathrm{AUC}_{0-24}$ of afatinib at the single point of $C_{0}$ and the measured $A C_{0-24}$ was lower than that at the single point of $C_{6}$ $\left(r^{2}=0.761\right.$ and 0.840 , respectively), the $95 \% \mathrm{CI}$ of the slopes and intercepts of the formulae obtained by bootstrap analysis also indicated acceptable accuracy and robustness for the prediction of $\mathrm{AUC}_{0-24}$ using the single point of $\mathrm{C}_{0}$. Therefore, the predicted $\mathrm{AUC}_{0-24}$ of afatinib with $\mathrm{C}_{0}$ alone was able to approximate the real $\mathrm{AUC}_{0-24}$. Consequently, the assessment of outpatients using an index of afatinib $C_{0}$ with a cut-off value of $28.5 \mathrm{ng} / \mathrm{mL}$ is also possible. In the LUX-Lung 3 and 6 trials, median progression-free survival was similar between patients who received a reduced dose of afatinib and those who did not [27]. Similarly, in the real-world setting, time to treatment failure and time to progression did not change with the daily afatinib dose [28,29]. Furthermore, in a phase I study of afatinib plus bevacizumab, the recommended dose was set at $30 \mathrm{mg} /$ day [30]. Therefore, it is 
important to adjust the dose of afatinib without hesitation because such adjustments are unlikely to affect efficacy. Our results can be used as an indicator for dose reduction owing to adverse effects.

Our results should be interpreted within the context of the study limitations. Unfortunately, in the current study, treatment with afatinib for patients with grade 3 diarrhea was halted before blood sampling for afatinib pharmacokinetics on day 15. Therefore, further studies are needed to determine the relationships between afatinib-induced grade 3 diarrhea and afatinib plasma concentrations. After beginning afatinib therapy, we may need to confirm the afatinib $C_{0}$ at an early time on day 8 after the beginning of therapy to reach a steady state.

\section{Conclusions}

Afatinib $\mathrm{AUC}_{0-24}$ of greater than or equal to $823.5 \mathrm{ng} \cdot \mathrm{h} / \mathrm{mL}$ and $\mathrm{C}_{0}$ of greater than or equal to $28.5 \mathrm{ng} / \mathrm{mL}$ could be used as cut-off values for the incidence of afatinib-induced grade 2 diarrhea. In addition, because the afatinib $C_{0}$ was related to $\mathrm{AUC}_{0-24}$, we could use $\mathrm{C}_{0}$ as a marker of therapeutic drug monitoring. Accordingly, we suggest monitoring the afatinib $\mathrm{C}_{0}$ on day 8 after the beginning of therapy to reach a steady state and adjusting the daily dose of afatinib as an index with a cut-off value of $28.5 \mathrm{ng} / \mathrm{mL}$.

Author Contributions: Conceptualization, H.Y., K.S., K.N. and M.M.; methodology, M.M.; investigation, H.Y.; resources, K.S., S.S., Y.O., M.A., M.T. and K.N.; formal analysis, H.Y. and M.M.; writing — original draft preparation, H.Y. and M.M.; writing—review and editing, H.Y. and M.M.; funding acquisition, H.Y. and M.M. All authors have read and agreed to the published version of the manuscript.

Funding: This research was funded by a grant (no. 20K07150 and 21H04217) from the Japan Society for the Promotion of Science, Tokyo, Japan.

Institutional Review Board Statement: This study was conducted according to the guidelines of the Declaration of Helsinki and approved by the Ethics Committee of Akita University School of Medicine (approval no. 790, 16 May 2011).

Informed Consent Statement: Informed consent was obtained from all patients involved in the study.

Data Availability Statement: The data presented in this study are available on reasonable request.

Acknowledgments: This work was supported by a grant (no. 20K07150 and 21H04217) from the Japan Society for the Promotion of Science, Tokyo, Japan.

Conflicts of Interest: The authors declare no conflict of interest.

\section{References}

1. Solca, F.; Dahl, G.; Zoephel, A.; Bader, G.; Sanderson, M.; Klein, C.; Kraemer, O.; Himmelsbach, F.; Haaksma, E.; Adolf, G.R. Target binding properties and cellular activity of afatinib (BIBW 2992), an irreversible ErbB family blocker. J. Pharmacol. Exp. Ther. 2012, 343, 342-350. [CrossRef]

2. Machiels, J.-P.H.; Haddad, R.I.; Fayette, J.; Licitra, L.F.; Tahara, M.; Vermorken, J.B.; Clement, P.M.; Gauler, T.; Cupissol, D.; Grau, J.J.; et al. Afatinib versus methotrexate as second-line treatment in patients with recurrent or metastatic squamous cell carcinoma of the head and neck progressing on or after platinum-based therapy (LUX-Head \& Neck 1): An open-label, randomised phase 3 trial. Lancet Oncol. 2015, 16, 583-594. [CrossRef]

3. Yang, J.C.-H.; Shih, J.-Y.; Su, W.-C.; Hsia, T.-C.; Tsai, C.-M.; Ou, S.-H.I.; Yu, C.-J.; Chang, G.-C.; Ho, C.-L.; Sequist, L.V.; et al. Afatinib for patients with lung adenocarcinoma and epidermal growth factor receptor mutations (LUX-Lung 2): A phase 2 trial. Lancet Oncol. 2012, 13, 539-548. [CrossRef]

4. Sequist, L.V.; Yang, J.C.-H.; Yamamoto, N.; O’Byrne, K.; Hirsh, V.; Mok, T.; Geater, S.L.; Orlov, S.; Tsai, C.-M.; Boyer, M.; et al. Phase III study of afatinib or cisplatin plus pemetrexed in patients with metastatic lung adenocarcinoma with EGFR mutations. JCO 2013, 31, 3327-3334. [CrossRef] [PubMed]

5. Katakami, N.; Atagi, S.; Goto, K.; Hida, T.; Horai, T.; Inoue, A.; Ichinose, Y.; Koboyashi, K.; Takeda, K.; Kiura, K.; et al. LUX-Lung 4: A phase II trial of afatinib in patients with advanced non-small-cell lung cancer who progressed during prior treatment with erlotinib, gefitinib, or both. JCO 2013, 31, 3335-3341. [CrossRef] [PubMed] 
6. Wu, Y.-L.; Zhou, C.; Hu, C.-P.; Feng, J.; Lu, S.; Huang, Y.; Li, W.; Hou, M.; Shi, J.H.; Lee, K.Y.; et al. Afatinib versus cisplatin plus gemcitabine for first-line treatment of Asian patients with advanced non-small-cell lung cancer harbouring EGFR mutations (LUX-Lung 6): An open-label, randomised phase 3 trial. Lancet Oncol. 2014, 15, 213-222. [CrossRef]

7. Park, K.; Tan, E.-H.; O’Byrne, K.; Zhang, L.; Boyer, M.; Mok, T.; Hirsh, V.; Yang, J.C.-H.; Lee, K.H.; Lu, S.; et al. Afatinib versus gefitinib as first-line treatment of patients with EGFR mutation-positive non-small-cell lung cancer (LUX-Lung 7): A phase 2B, open-label, randomised controlled trial. Lancet Oncol. 2016, 17, 577-589. [CrossRef]

8. Tamura, K.; Nukiwa, T.; Gemma, A.; Yamamoto, N.; Mizushima, M.; Ochai, K.; Ikeda, R.; Azuma, H.; Nakanishi, Y. Real-world treatment of over 1600 Japanese patients with EGFR mutation-positive non-small cell lung cancer with daily afatinib. Int. J. Clin. Oncol. 2019, 24, 917-926. [CrossRef] [PubMed]

9. Kim, Y.; Lee, S.-H.; Ahn, J.S.; Ahn, M.-J.; Park, K.; Sun, J.-M. Efficacy and safety of afatinib for EGFR-mutant non-small cell lung cancer, compared with gefitinib or erlotinib. Cancer Res. Treat. 2018, 51, 502-509. [CrossRef]

10. Takeda, M.; Okamoto, I.; Nakagawa, K. Pooled safety analysis of EGFR-TKI treatment for EGFR mutation-positive non-small cell lung cancer. Lung Cancer 2015, 88, 74-79. [CrossRef]

11. Ding, P.N.; Lord, S.J.; Gebski, V.; Links, M.; Bray, V.; Gralla, R.J.; Yang, J.C.-H.; Lee, C.K. Risk of treatment-related toxicities from EGFR tyrosine kinase inhibitors: A meta-analysis of clinical trials of gefitinib, erlotinib, and afatinib in advanced EGFR-mutated non-small cell lung cancer. J. Thoracic Oncol. 2017, 12, 633-643. [CrossRef]

12. Kato, T.; Yoshioka, H.; Okamoto, I.; Yokoyama, A.; Hida, T.; Seto, T.; Kiura, K.; Massey, D.; Seki, Y.; Yamamoto, N. Afatinib versus cisplatin plus pemetrexed in Japanese patients with advanced non-small cell lung cancer harboring activating EGFR mutations: Subgroup analysis of LUX-Lung 3. Cancer Sci. 2015, 106, 1202-1211. [CrossRef]

13. Yang, J.C.-H.; Reguart, N.; Barinoff, J.; Köhler, J.; Uttenreuther-Fischer, M.; Stammberger, U.; O’Brien, D.; Wolf, J.; Cohen, E.E. Diarrhea associated with afatinib: An oral ErbB family blocker. Expert Rev. Anticancer Ther. 2013, 13, 729-736. [CrossRef]

14. Wind, S.; Schmid, M.; Erhardt, J.; Goeldner, R.-G.; Stopfer, P. Pharmacokinetics of afatinib, a selective irreversible ErbB family blocker, in patients with advanced solid tumours. Clin. Pharmacokinet. 2013, 52, 1101-1109. [CrossRef]

15. Wind, S.; Schnell, D.; Ebner, T.; Freiwald, M.; Stopfer, P. Clinical pharmacokinetics and pharmacodynamics of afatinib. Clin. Pharmacokinet. 2017, 56, 235-250. [CrossRef]

16. Sato, J.; Morikawa, N.; Chiba, R.; Nihei, S.; Moriguchi, S.; Saito, H.; Yamauchi, K.; Kudo, K. Case series on the association between blood levels and side effects of afatinib maleate. Cancer Chemother. Pharmacol. 2017, 80, 545-553. [CrossRef] [PubMed]

17. Hayashi, H.; Iihara, H.; Hirose, C.; Fukuda, Y.; Kitahora, M.; Kaito, D.; Yanase, K.; Endo, J.; Ohno, Y.; Suzuki, A.; et al. Effects of pharmacokinetics-related genetic polymorphisms on the side effect profile of afatinib in patients with non-small cell lung cancer. Lung Cancer 2019, 134, 1-6. [CrossRef] [PubMed]

18. Nakao, K.; Kobuchi, S.; Marutani, S.; Iwazaki, A.; Tamiya, A.; Isa, S.; Okishio, K.; Kanazu, M.; Tamiya, M.; Hirashima, T.; et al. Population pharmacokinetics of afatinib and exposure-safety relationships in Japanese patients with EGFR mutation-positive non-small cell lung cancer. Sci. Rep. 2019, 9, 18202. [CrossRef] [PubMed]

19. Miura, M.; Sato, K.; Miura, H.; Niioka, T.; Kobayashi, H.; Narita, C.; Ito, H. A limited sampling strategy for estimation of the area under the plasma concentration-time curve of gefitinib. Ther. Drug Monitor. 2014, 36, 24-29. [CrossRef]

20. Yokota, H.; Sato, K.; Okuda, Y.; Kobayashi, H.; Takeda, M.; Asano, M.; Ito, H.; Miura, M. Effects of histamine 2-receptor antagonists and proton pump inhibitors on the pharmacokinetics of gefitinib in patients with non-small-cell lung cancer. Clin. Lung Cancer 2017, 18, e433-e439. [CrossRef]

21. Nagahama, M.; Ozeki, T.; Suzuki, A.; Sugino, K.; Niioka, T.; Ito, K.; Miura, M. Association of lenvatinib trough plasma concentrations with lenvatinib-induced toxicities in Japanese patients with thyroid cancer. Med. Oncol. 2019, 36, 39. [CrossRef]

22. Efron, B.; Tibshirani, R.J. An introduction to the bootstrap. Monographs on Statistics and Applied Probability, No. 57. Chapman and Hall, London, 436 p. Monogr. Stat. Appl. Probab. 1993, 57, 436.

23. Freiwald, M.; Schmid, U.; Fleury, A.; Wind, S.; Stopfer, P.; Staab, A. Population pharmacokinetics of afatinib, an irreversible ErbB family blocker, in patients with various solid tumors. Cancer Chemother. Pharmacol. 2014, 73, 759-770. [CrossRef] [PubMed]

24. Hopkins, A.M.; Nguyen, A.-M.; Karapetis, C.S.; Rowland, A.; Sorich, M.J. Risk factors for severe diarrhea with an afatinib treatment of non-small cell lung cancer: A pooled analysis of clinical trials. Cancers 2018, 10, 384. [CrossRef] [PubMed]

25. Duan, T.; Cil, O.; Thiagarajah, J.R.; Verkman, A.S. Intestinal epithelial potassium channels and CFTR chloride channels activated in ErbB tyrosine kinase inhibitor diarrhea. JCI Insight 2019, 4, e126444. [CrossRef]

26. Kim, Y.; Quach, A.; Das, S.; Barrett, K.E. Potentiation of calcium-activated chloride secretion and barrier dysfunction may underlie EGF receptor tyrosine kinase inhibitor-induced diarrhea. Physiol. Rep. 2020, 8, e14490. [CrossRef] [PubMed]

27. Yang, J.C.-H.; Sequist, L.V.; Zhou, C.; Schuler, M.; Geater, S.L.; Mok, T.; Hu, C.-P.; Yamamoto, N.; Feng, J.; O’Byrne, K.; et al. Effect of dose adjustment on the safety and efficacy of afatinib for EGFR mutation-positive lung adenocarcinoma: Post hoc analyses of the randomized LUX-Lung 3 and 6 trials. Ann. Oncol. 2016, 27, 2103-2110. [CrossRef] [PubMed]

28. Halmos, B.; Tan, E.-H.; Soo, R.A.; Cadranel, J.; Lee, M.K.; Foucher, P.; Hsia, T.-C.; Hochmair, M.; Griesinger, F.; Hida, T.; et al. Impact of afatinib dose modification on safety and effectiveness in patients with EGFR mutation-positive advanced NSCLC: Results from a global real-world study (RealGiDo). Lung Cancer 2019, 127, 103-111. [CrossRef] 
29. Liu, C.-Y.; Wang, C.-L.; Li, S.-H.; Hsu, P.-C.; Chen, C.-H.; Lin, T.-Y.; Kuo, C.-H.; Fang, Y.-F.; Ko, H.-W.; Yu, C.-T.; et al. The efficacy of $40 \mathrm{mg}$ versus dose de-escalation to less than $40 \mathrm{mg}$ of afatinib (Giotrif) as the first-line therapy for patients with primary lung adenocarcinoma harboring favorable epidermal growth factor mutations. Oncotarget 2017, 8, 97602-97612. [CrossRef] [PubMed]

30. Ko, R.; Shukuya, T.; Imamura, C.K.; Tokito, T.; Shimada, N.; Koyama, R.; Yamada, K.; Ishii, H.; Azuma, K.; Takahashi, K. Phase I study of afatinib plus bevacizumab in patients with advanced non-squamous non-small cell lung cancer harboring EGFR mutations. Transl. Lung Cancer Res. 2021, 10, 183-192. [CrossRef] [PubMed] 